Federal Reserve Bank of Minneapolis

Research Department

\title{
The Suffolk Bank and the Panic of 1837: How a Private Bank Acted as a Lender-of-Last-Resort
}

\author{
Arthur J. Rolnick, Bruce D. Smith, \\ and Warren E. Weber*
}

Working Paper 592

December 1998

\begin{abstract}
Before the establishment of federal deposit insurance, the U.S. experienced periodic banking panics, during which banks suspended specie payments and reduced lending. There was often a corresponding ec onomic slowdown. The Panic of 1837 is considered one of the worst banking panics, and it coincided with a slowdown that lasted for almost five years. The economic disruption was not uniform across the cou ntry, however. The slowdown in New England was substantially less severe than elsewhere. Here we suggest that the Suffolk Bank, a private bank, was one reason for New England's relative success. We argue that the Suffolk Bank's provision of note-clearing and lender of last resort services (via the Suffolk Banking System) lessened the effects of the Panic of 1837 in New England relative to the rest of the country, where no bank provided such services.

*Rolnick, Federal Reserve Bank of Minneapolis; Smith, University of Texas at Austin; Weber, Federal Reserve Bank of Minneapolis and University of Minnesota. The authors thank the Baker Library, Harvard Business School for the materials provided from its Suffolk Bank Collection. The views expressed herein are those of the author(s) and not necessarily those of the Federal Reserve Bank of Minneapolis or the Federal Reserve System.
\end{abstract}


Before the establishment of federal deposit insurance in 1935, the U.S. economy was subject to periodic banking panics. During such panics, banks often suspended payments and reduced lending. There was often a corresponding slowdown in economic activity. One of these panics, the Panic of 1837, is considered one of the worst banking disruptions in U.S. history. Most banks suspended the payment of specie, and many banks either closed or failed. Further, the disruption in banking that began with the Panic of 1837 coincided with a slowdown in the U.S. economy that lasted for almost five years.

The effects of the Panic of 1837, however, were not uniform across the country. The South, which confronted declining cotton prices at the same time that it was in the throes of the banking panic, was the most adversely affected region. The middle-Atlantic states fared somewhat better than the South, presumably because the economies of the middle-Atlantic states were much less dependent on the cotton industry. But the region that fared the best was New England, where the banking disruptions and the economic slowdown were substantially less severe than they were in the rest of the country.

Why did New England's economy do so well relatively, especially compared with other regions of the country that were not heavily dependent on cotton? In this paper, we suggest that one reason for New England's relative success may have been the behavior of a private bankthe Suffolk Bank of Boston. The Suffolk Bank provided note-clearing services to banks throughout New England (via a unique system known as the Suffolk Banking System) and acted as a lender-of-last-resort. We contend that the Suffolk Bank's provision of such services lessened the effects of the Panic of 1837 in New England relative to the rest of the country, where these services did not exist. 
By 1836, the Suffolk Bank had become a clearinghouse for virtually all the banknotes that circulated in New England. We think the clearing of banknotes played an important role in allowing the banks of New England to resume payments in specie and to resume their normal level of lending sooner than banks in other parts of the country. Further, as part of the Suffolk Banking System's note-clearing business, the Suffolk Bank offered a line of credit to all System members that was available even during times of financial stress. Indeed, we will show that during the Panic of 1837 and in the immediate years that followed, the Suffolk Bank provided a relatively large amount of short-term credit to the banks of New England. We surmise that because this note-clearing business was so lucrative, the Suffolk Bank had an incentive to be, in effect, a lender-of-last-resort.

Taken together, the Suffolk Bank's activities as a net-clearer of banknotes and as a lender-of-last-resort meant that the contraction of loans and the contraction of the money supply in New England were smaller than those in other parts of the country.

We proceed as follows: We first present a brief history of the Panic of 1837 and the ensuing economic slowdown that engulfed the U.S. economy. We then present evidence that New England's economy outperformed economies in other regions of the United States. This evidence is largely based on a contrast between Massachusetts' and Pennsylvania's economies: the former we view as a good proxy for New England's economy, the latter as a good proxy for economies outside New England that were not heavily dependent on cotton. Finally, we present evidence on why we think the Suffolk Bank played an important role in New England's economic performance. 


\section{The Panic of 1837}

The Panic of 1837 affected the entire U.S. banking system. The first bank suspensions occurred in Natchez, Mississippi, on May 4, 1837. The banks in Montgomery, Alabama, followed on May 9. Bank suspensions hit the North on May 10, when the banks in New York City suspended specie payments (McGrane 1924, Chap. 4). Bank suspensions then rapidly spread to other parts of the country. On May 11, the banks in Albany, Hartford, Philadelphia, Providence, and Baltimore suspended, followed on May 12 by the banks in Mobile and Boston and on May 13 by the banks in New Orleans. By the end of May, virtually all the banks in the country had suspended. The only reported exception was the State Bank of Missouri (Martin 1886, p. 30). ${ }^{1}$

The length of suspensions and the permanence of the subsequent resumptions of specie payments varied in different parts of the country. On April 16, 1838, two prominent Boston banks were the first to resume specie payments. By the end of May, the banks of New England and New York had resumed.

Resumption was much slower to occur in other parts of the country, however. Most banks in the rest of the country did not resume until the fall of 1838. In August, the United States Bank of Pennsylvania (formerly the Second Bank of the United States), other banks in

\footnotetext{
${ }^{1} \mathrm{We}$ follow the terminology of the time and define bank suspensions as times when banks stopped redeeming their notes in specie on demand. Banks did not close their doors, but remained open for business. This point is made explicitly in the suspension resolution adopted by the banks of New York City on May 10, 1837:

In the meantime the notes of all the banks will be received at the different banks, as usual, in payment of debts, and in deposite; and as the indebtedness of the community to the bank exceeds three times the amount of their liabilities to the public, it is hoped and expected that the notes of the different banks will pass current, as usual, and that the state of the times will soon be such as to render the resumption of specie payments practicable (Niles' 1837, vol. 52, May 13, p. 162).
} 
Philadelphia and the rest of Pennsylvania, and the banks in Maryland resumed. Shortly thereafter, banks in the South resumed.

Historians are still debating the causes of the Panic of 1837. For example, some point to President Andrew Jackson's successful campaign to prevent the renewal of the charter of the Second Bank of the United States. (See Hammond 1957, pp. 438-45.) As a result, the Second Bank's federal charter expired in 1836, and the bank had to acquire a state charter from Pennsylvania. By 1836, the Second Bank had lost its federal deposits and its central banking responsibility of maintaining a sound currency. These historians place at least part of the blame for the Panic of 1837 on the absence of a federally chartered bank. The Second Bank of the United States had provided a discipline on state bank behavior by returning notes of banks that it deemed too risky and was "a corrective for the evils of inflation" (Hammond 1957, p. 443).

A second possible contributor to the Panic of 1837 was the so-called Specie Circular-an executive order issued in July of 1836 under which only specie would be accepted as payment for public land. (See Timberlake 1960.) Before the Specie Circular, the federal government was willing to accept banknotes and certified bank checks as payment. The Specie Circular, along with a federal budget that had been in surplus for a few years, may have disrupted the flow of capital around the country. The argument is that because of the Specie Circular and the mounting federal surplus, the federal government was collecting a large amount of specie from banks around the country and redistributing the proceeds to other banks. The process of collecting and redistributing specie meant that more specie was in transit (and, hence, outside the banking system) than before; therefore, banks had to contract their lending.

Other historians argue that government policies had little to do with the panic. They point to a third possible cause: underlying economic factors. In particular, Temin (1969) points 
to falling cotton prices and falling farm incomes, which led to a high rate of mortgage defaults. In December of 1836, cotton prices had reached a high of 15.3 cents per pound. They began to fall sharply in 1837. By May of 1837 , cotton prices were down 25 percent to 11.5 cents per pound (Gray 1933, p. 1027).

Regardless of the cause or causes, the Panic of 1837 appears to have been followed by a widespread economic slowdown, which some historians describe as a "severe depression," that lasted in parts of the country for close to five years (Goldin and Margo 1989, p. 1). Due to the lack of early U.S. economic data, estimates of real gross national product (GNP) are, at best, very rough. Nevertheless, according to one of the more recent estimates (Myers 1992, Table IV), the U.S. economy slowed dramatically in the years immediately following the Panic of 1837. Between 1820 and 1836, real GNP grew at close to an 8 percent annual rate. Moreover, between 1830 and 1836, real GNP grew at a 10 percent annual rate. In contrast, real GNP declined in 1837 and grew at only a 1.3 percent annual rate from 1836 to 1840 . An overall index of stock prices reflects this slowdown as stock prices declined by over 50 percent from their high in May 1935 to their low in January 1843.

More narrow and more qualitative measures of economic activity are consistent with the view of the severe slowdown painted by these broad measures of economic activity. McGrane (1924) reports that in 1837, unemployment was widespread throughout the eastern United States. More specifically, he notes that 6,000 masons, carpenters, and other workers connected with the building trades had lost their jobs. And in the state of New York, approximately 50,000 workers were idle. Further, McGrane (1924) reports that between 1836 and 1838, both imports and exports declined by roughly $\$ 49$ million. [In 1836 , imports were $\$ 190$ million and exports slightly under \$129 million (Martin 1886, p. 30).] McGrane (1924, p. 132) also reports that there was a 
steep decline in land sales during these years and that the condition of the laborer steadily declined and reached its lowest point in 1841.

The South's economy appears to have fared worse than the rest of the country. As noted above, the price of cotton dropped sharply just before the Panic of 1837. On April 15, 1837, Niles' Weekly Register (vol. 52, pp. 118, 119) declared that southern merchants could not pay five cents on the dollar of what they owed to New York banks. By July of 1839, the U.S. economy was reported to be in worse shape than during the war with England. And in 1841, the state of Florida defaulted on its debt.

Another piece of evidence suggesting that a prolonged slowdown occurred after the Panic of 1837 is the advent of another widespread bank suspension (Niles' 1839, vol. 57). This slowdown began in 1839 and lasted for at least two years. On October 9, the banks in Philadelphia suspended, and by year-end, most of the banks in the interior of Pennsylvania followed. On October 10, the banks in Baltimore suspended. By the following week, the banks in Providence, Richmond, and Norfolk; all but one bank in the District of Columbia; and all but one bank in Cincinnati had suspended. Many of the banks in Louisville suspended shortly after hearing that the banks in Cincinnati had suspended. By the end of 1839, most of the banks in Tennessee, Indiana, and Louisiana had also suspended. The suspension of 1839 , however, was not as widespread as the suspension of 1837 . According to Niles' (1839, vol. 57), the banks in the following states did not suspend: New Jersey, New York, and the New England states except Rhode Island (the only state in New England that was not part of the Suffolk Banking System).

\section{The New England Economy}

In this section, we show that the New England economy appears to have fared better than economies in other parts of the country. In particular, we compare production and stock price 
data from Massachusetts (the largest economy in New England) and Pennsylvania (one of the largest economies outside New England that was not heavily dependent on cotton).

While state-by-state measures of aggregate output do not exist, there are estimates of textile production in Massachusetts (one of that state's leading industries) and for anthracite coal production in Pennsylvania (one of that state's leading industries). The numbers suggest that the Panic of 1837 had a more dampening affect on real economic activity in Pennsylvania than in Massachusetts.

Between 1826 and 1836, the annual rate of increase in textile production in Massachusetts was 46 percent, although the rate had slowed considerably by the 1830 s. Between 1830 and 1836, the rate was 20 percent. And while the pace of growth in textile production continued to slow through the post-panic years, it still averaged over 7 percent annually between 1837 and 1840. (Recall that the national economy over this period was growing at only a 1.3 percent annual rate.)

In contrast to Massachusetts' textile industry, Pennsylvania's anthracite coal industry was expanding in the first half of the 1830s, but declined during the post-panic years. Between 1820 and 1836, the annual rate of increase in anthracite coal production in Pennsylvania was over 14 percent. Further, the rate was rising sharply in the 1830 s. Between 1830 and 1836, the rate was close to 50 percent. The health of this industry took a dramatic change for the worse after the Panic of 1837. Between 1837 and 1840, anthracite coal production in Pennsylvania decreased at an annual rate of 1 percent. (See U.S. Bureau of the Census 1975, p. 593; National Bureau of Economic Research 1966, p. 221.)

Another indicator of the relative economic well-being of the two economies represented by Massachusetts and Pennsylvania is a comparison of indices of railroad stock prices given in 
Chart 1. This comparison gives an even stronger picture of the New England economy relative to that of the middle-Atlantic states. ${ }^{2}$ We find that while the prices of the railroad stocks in New England went up during the post-panic years, stock prices declined by almost 50 percent in the middle-Atlantic region.

Finally, another revealing sign that Massachusetts' economy did better than Pennsylvania's is that the latter suffered a second bank suspension, while the former did not. In October of 1839, just over a year after the Pennsylvania banks resumed, the banks of Pennsylvania (and many other banks around the country) suspended specie payment again. This suspension lasted several years. As in the previous suspension, the amount of loans made by the Pennsylvania banks and the amount of their bills in the hands of the public declined precipitously. In contrast, Massachusetts banks avoided a second suspension, and banking activity continued at a steady pace.

\section{The Suffolk Bank's Effects}

New England's economy fared better than the rest of the country during and after the Panic of 1837 for several possible reasons. Clearly, New England fared better than the South because it was less dependent on cotton. But why did New England fare better than other northern states? We argue that the Suffolk Bank was a key to New England's economic performance.

After presenting a brief history of the Suffolk Bank and the Suffolk Banking System, we explain how the Suffolk Bank's note-clearing business and interbank lending policy could have contributed to New England's better economic performance during this period.

\footnotetext{
${ }^{2}$ The indices were constructed by Arthur Cole and consist of stock prices for five New England railroads and stock prices for five middle-Atlantic railroads. (See Smith and Cole 1935.)
} 


\section{A Brief History}

On February 10, 1818, the Suffolk Bank became the seventh bank to be chartered in Boston. Within a year, the Suffolk Bank entered the note-brokering business - the buying and selling of country (non-Boston) banknotes, also known as foreign money. While the Suffolk Bank's note-brokering business was never profitable, it provided the testing ground for the development of a very profitable, region-wide note-clearing system. The note-clearing business, in turn, gave the Suffolk Bank the incentive and the wherewithal to act as a guardian of the entire New England banking system.

By 1824, the Suffolk Bank had given up the note-brokering business and devised a new strategy for dealing with foreign money. The Suffolk Bank formed a coalition with the six other Boston banks to export country banknotes, with the goal of eliminating foreign money from the city of Boston. Each coalition member contributed between $\$ 30,000$ and $\$ 60,000$ to a fund for a total of $\$ 300,000$. This fund was to be used by the Suffolk Bank to purchase country banknotes at "the same or less discount than the New England Bank, or other banks in Boston, received [them], and should send [them] home for redemption" (Whitney 1878, p. 15). Such purchases were to continue indefinitely until country notes ceased to circulate in Boston. This attempt to drive country banknotes out of Boston was unsuccessful.

The failure of this note-purchasing strategy eventually led to the end of the coalition of Boston banks, but not to the end of the Suffolk Bank's role in the foreign money business. Indeed, the Suffolk Bank was soon to become the dominant player in this business. In May of 1825, the coalition, having all but given up on driving foreign money out of Boston, suggested that the Suffolk Bank begin a new note-clearing business. The Suffolk Bank would provide a clearinghouse that would allow banks in the region to deposit their foreign money with the Suf- 
folk Bank at par. The Suffolk Bank would then net-clear the banknotes it received. No longer would the Suffolk Bank merely buy country banknotes in order to send them back to the issuing bank for redemption; instead, the Suffolk Bank would accept and clear at par all country banknotes deposited by banks that chose to participate in the system (Redlich 1947, p. 74). By 1826, the city banks had withdrawn from the original note-brokering coalition and become members of the new clearinghouse (Mullineaux 1987, p. 890; Directors' Records of the Suffolk Bank, 1826).

The Suffolk Bank's note-clearing business (known as the Suffolk Banking System) was similar in many ways to the old note-brokering business. To participate in the System, a country bank had to maintain a noninterest-bearing, permanent deposit with the Suffolk Bank or with another Boston member of the Suffolk Banking System: for each $\$ 100,000$ of capital, a country bank had to hold $\$ 2,000$ on deposit. A country bank had to maintain an additional noninterestbearing deposit that was, on average, sufficient to redeem its notes received by the Suffolk Banking System. Boston banks had to maintain only a noninterest-bearing, permanent deposit. This deposit was initially set at $\$ 30,000$, but was gradually reduced to $\$ 5,000$.

This new arrangement produced two innovations. One innovation was that banknotes were cleared by netting the accounts of member banks. Before this time, no net-clearing system for banknotes had been established in the United States. For example, the (Second) Bank of the United States, which dealt heavily in the notes of state banks, practiced gross-clearing-simply presenting each state bank's notes for redemption in specie. The other innovation was that the Suffolk Bank offered loans-in effect, overdraft privileges - to members of the System. It was these innovations that made the note-clearing business so attractive to all participating banks and ultimately so profitable. 
The netting of banknotes worked as follows: Each day, the notes deposited by participating banks at the Suffolk Bank were sorted. The following day, the net amount was posted to the account of the appropriate bank. The notes of nonparticipating banks were sent to the issuing bank for redemption as quickly as possible.

The process of net-clearing had value to Suffolk Banking System members because it lowered the cost of redeeming banknotes. Because fewer notes had to travel back to the issuing bank for redemption, less specie had to be physically shipped between banks at a time when such shipment was relatively costly.

The net-clearing of banknotes opened up another business to the Suffolk Bank. It became a major lender to other banks. This was a service that apparently was not fully developed at the time, and it was a service that the Suffolk Bank was well-positioned to provide. As a net-clearer, the Suffolk Bank naturally offered the analog of overdraft privileges (at a price). Moreover, by holding member banks' deposits and clearing their notes, the Suffolk Bank established strong relationships with banks and likely had an advantage over other potential lenders in monitoring banks' activities. In short, we think that the Suffolk Bank was able to exploit economies of scope in combining its clearing and lending activities.

In its early stages, the Suffolk System was relatively small in both its clearing and its lending activities. In the summer of 1824 , the Suffolk Bank was receiving only about $\$ 300,000$ a month in country banknotes. This amount grew to $\$ 2,000,000$ a month by the end of 1825 , and by 1837 , it was well over $\$ 6,000,000$ a month (Trivoli 1979 , pp. 15,21 ). To put these numbers in perspective, note that monthly clearing in 1825 amounted to approximately one-half of the stock of notes in circulation in Massachusetts; by 1837, monthly clearing was close to the entire 
stock. And by 1837, virtually all the banks in New England were members of the Suffolk Banking System.

\section{Why the Suffolk Bank Made Such a Difference}

We think the Suffolk Bank helped to produce a more robust economy in New England in two ways. One way was by providing for the net-clearing of notes. Because notes of New England banks were being net-cleared during the 1837 suspension, banks in New England were able to reduce their outstanding notes with a smaller reduction in their outstanding loans than were the banks of Pennsylvania, which did not have access to such a note-clearing system. This meant that there was less disruption in the provision of intermediation services by New England banks. The other way was by acting as a lender-of-last-resort. The overall result was that the loan volume and the money supply fell less in New England than in Pennsylvania.

To the best of our knowledge, the Suffolk Bank's net-clearing system for banknotes was unique in the United States at the time. In other parts of the country, banknotes were mostly gross-cleared; that is, a bank sent the notes of other banks it received back to those banks for payments in specie. We contend that in bank panics and suspensions, a net-clearing system like the Suffolk Banking System, in which notes are credited and debited to banks' accounts and netcleared at the end of the day, should lessen the need for banks to curtail their lending and, hence, lessen the effects of a bank panic and suspension on real economic activity.

Consider the problem a bank faces during a suspension. At some point in the future, the bank will be required to resume and, once again, redeem its outstanding notes (and, perhaps, deposits) in specie on demand. In preparation for this event, the bank would want to increase its ratio of specie to notes. 
One way to increase its specie-notes ratio is for the bank to increase its specie holdings, but in a suspension, this is very unlikely to occur to any great extent. Other banks are certainly not going to part with their specie, because they are in the same position. And the general public is unlikely to deposit specie, since the public is concerned about the acceptability of bank liabilities.

This situation leaves the bank with the other way of increasing its specie-notes ratio-decreasing the amount of its notes outstanding. The bank can do this by calling in loans or by not renewing loans when they mature, because the bank will, in general, receive banknotes as the form of loan repayment. The problem, of course, is that there is no guarantee that the bank will get its own notes as the loan repayment, because generally during bank suspensions of this period, banks agreed to keep accepting each other's notes. Because the bank will not redeem its received notes in specie, its own notes will be returned to it by other banks only to the extent that other banks think the receiving bank is holding some of their notes. Since such information is probably costly to obtain, we would expect interbank note redemptions to be low during suspensions, causing banks to have to call in more loans than the amount of notes they want to get out of circulation. Another consequence is that during suspensions, banks find themselves holding a larger quantity of other banknotes than under normal circumstances.

The problem is less severe, however, for banks that operate under a net-clearing system like the Suffolk Banking System. Under this System, when New England banks received notes of other banks, they could deposit those notes at the Suffolk Bank. New England banks would receive back from the Suffolk Bank any of their notes that had been deposited by other members of the System. This occurred regardless of whether or not banks were suspended. Once a bank had received its notes back from the Suffolk Bank, it could, of course, then remove them from 
circulation. In effect, the Suffolk Banking System helped ensure that when a bank called in a loan, it would receive its own notes as payment. As a result, a bank that was member of a netclearing system had to make a smaller reduction in loans to achieve a given reduction in notes outstanding than a bank that was not part of such a system.

If this argument is correct, we should find that during the period we are examining, New England banks reduced loans to a lesser extent and were holding fewer notes of other banks than banks in other parts of the county. Using Massachusetts and Pennsylvania as proxies, we think the evidence supports this argument.

Bank loans in both states during the period are plotted in Chart 2. (The shaded areas in this and all subsequent charts indicate periods during which banks were suspended; recall, however, that Massachusetts' banks were not suspended during the second shaded period.) In Chart 2, we see that between May 1, 1837, and June 1, 1838, bank loans in Pennsylvania declined from $\$ 49.3$ million to $\$ 38.0$ million - a decline of $\$ 11.3$ million (roughly 23 percent). Over the same period, bank loans in Massachusetts declined from $\$ 57.8$ million to $\$ 48.2$ million—a smaller decline of $\$ 9.6$ million (17 percent). ${ }^{3}$

The behavior of notes of other banks, plotted in Chart 3, also supports our argument. Between June 1, 1837, and June 1, 1838, notes of other banks held by Pennsylvania banks increased by $\$ 1.39$ million, from $\$ 2.74$ million to $\$ 4.13$ million. In contrast, over this period notes of other banks held by Massachusetts banks actually declined. These notes totaled $\$ 3.10$ million right after the panic began, but had fallen by roughly $\$ 750,000$ to $\$ 2.36$ million by the time banks resumed specie payments.

\footnotetext{
${ }^{3}$ The difference in bank loan activity is much more dramatic if we compare the decline in Philadelphia to the decline in Boston.
} 
The Suffolk Bank's role as a lender-of-last-resort was complementary to its role as a netclearer of banknotes in that, while net-clearing lessened the impact of a suspension of payments, acting as a lender-of-last-resort made suspensions less likely.

During this period, virtually every bank faced redemption demands for its notes both from the public and from other banks that received its notes in the course of business. To avoid suspending payments and the possible legal actions that would ensue unless there was a general suspension, a bank had to have specie on hand to meet such demands.

A bank could have difficulty meeting redemption demands under two circumstances. One would be if a bank experienced a "bad draw," an extended sequence of extraordinarily high redemption demands. The other would be a general decline in the public's confidence in the banking system. Under either circumstance, a bank would want to decrease its note issues and, as a consequence, its intermediation activities. (For the reasons given above, the following discussion implicitly assumes that it is difficult for a bank to increase its specie holdings under these circumstances.)

A bank faces a less severe specie reserve problem if the Suffolk Bank acts as a lender-oflast-resort. While a bank that is a member of the Suffolk Banking System still has to have enough specie on hand to meet over-the-counter specie redemption demands on the part of the public, it does not have to be as concerned about such demands from other banks, because it can obtain a short-term credit to the account it is required to maintain with the Suffolk Bank. This credit can then be transferred to other banks' balances with the Suffolk Bank to meet their redemption demands. Thus, given similar circumstances, members of the Suffolk Banking System will be less likely to have to suspend specie payments and, as a consequence, will not necessarily want to reduce their loans outstanding as much as banks not in such a system. 
There is evidence that the Suffolk Bank acted as a lender-of-last-resort during the Panic of 1837 and during the resumption of specie payments in the following year. This evidence comes from the Suffolk Bank's balance sheet. During the period under consideration, most banks had an ongoing relationship with at least one other bank and, in most cases, several other banks. These relationships were of the following kinds: Banks held notes of other banks, which appeared on the assets side of their balance sheets as "bills or notes of other banks." Banks accepted deposits of other banks, which appeared on the liabilities side of their balance sheets as "due to other banks." In the case of the Suffolk Bank, the permanent deposits of members of the Suffolk Banking System appeared in this balance sheet entry. Banks also had deposits at and made loans to other banks, which appeared on the assets side of their balance sheets as "due from (or by) other banks." In the case of the Suffolk Bank, lending to other banks appeared in this balance sheet entry.

From records of Directors meetings during this period, we know that the Suffolk Bank made loans to other banks and that it did not have large deposits at other banks. Thus, we would argue that the item "due from other banks" on the Suffolk Bank's balance sheet consisted almost exclusively of its provision of liquidity to other banks through interbank lending. The amount of such lending by the Suffolk Bank during this period is shown in Chart 4. Notice that the Suffolk Bank's lending to other banks increased going into the Panic of 1837, and it remained high during the first suspension. What is important for our argument, however, is that the amount of lending to other banks remained high throughout the period of resumption, a period during which there was arguably a higher-than-usual level of demand for note redemption in specie. The Suffolk Bank's lending to other banks declined during the second period of suspension. However, since this suspension was only by banks outside of New England, we argue that bank 
redemption demands had returned to more normal levels in New England, and banks had to rely less on the Suffolk Bank's discount window.

The behavior of the Suffolk Bank contrasts markedly with that of large Philadelphia banks during the period. The amounts of "due from other banks" for several large Philadelphia banks and for the Suffolk Bank are plotted in Chart 5. While the "due froms" for large banks in Philadelphia moved in a similar manner to those of the Suffolk Bank during the first suspension, they declined precipitously during the 1838 resumption and did not build up again until well into the second suspension. Thus, during the resumption period, when Pennsylvania banks presumably would have wanted to be able to borrow from other banks to meet note redemption demands rather than paying out specie, as we have argued above, large Philadelphia banks did not provide this service.

In fact, a case can be made that the run-up in the "due froms" for large Philadelphia banks during the suspensions was not due to more interbank lending by these banks, but simply was due to the problems of clearing banknotes under a gross-clearing scheme. As discussed above, when banks are suspended and no net-clearing system is in place, as was the case in Pennsylvania and the surrounding area, it is harder for banks to redeem the notes of other banks. Thus, the run-up in "due froms" for large Philadelphia banks may simply represent notes of other banks that these Philadelphia banks presented for redemption, but for which Philadelphia banks had not yet received any form of payment either in specie, which was not required because banks were suspended, or by the return of some of their own notes. Note that this explanation of the data in Chart 5 is consistent with the fall in "due froms" during the period of resumption when, presumably, Philadelphia banks were getting specie for the notes presented for redemption. 
The discussion to this point has not addressed two questions. One is whether the Suffolk Bank's lending was a large enough part of interbank redemption demands for its lender-of-lastresort activities to make a difference. One piece of evidence supporting the contention that it was comes from Whitney (1878), who states that in 1841, the Suffolk Bank was clearing approximately $\$ 9$ million in banknotes per month. Thus, the Suffolk Bank's lending of an average of $\$ 1.1$ million during this period was equal to about two days' worth of note-clearing. Further, Chart 4 shows that toward the middle of 1839, when banks outside New England were about to suspend again, the Suffolk Bank's lending to other banks was approximately equal to the amount that other banks have deposited with it, which means that the Suffolk Banking System was essentially running entirely on the credit of the Suffolk Bank at this time.

The other question is why banks would have confidence in the Suffolk Bank and accept deposits at the Suffolk Bank as payment for another bank's notes rather than demanding specie either from the issuing bank or from the Suffolk Bank. Here, we argue, the answer lies in the high ratio of specie to net demand liabilities (bills plus deposits plus "due tos" less "due froms") that the Suffolk Bank was able to maintain. The high ratio, especially after resumption in 1838, should have made Suffolk Bank credit virtually as good as specie.

In Chart 6, we plot the ratio of specie to net demand liabilities for the Suffolk Bank and for all banks in Massachusetts other than the Suffolk Bank during this period. We see that through the first suspension and the subsequent resumption, the two ratios are very close. However, when banks outside New England suspended for the second time, the Suffolk Bank's ratio jumped higher than one and remained much higher than the ratio for other Massachusetts banks, at least until banks throughout the country had resumed for the second time. 
Finally, we have argued above that the Suffolk Bank's activities as a net-clearer and a lender-of-last-resort, taken together, should have caused the reductions in loan volume and in the money supply to be less in New England than in the rest of the country. That this was true from loan data, at least when Massachusetts is compared with Pennsylvania, was discussed above and shown in Chart 2. We now make the same comparison for the money supply. Since banknotes were the bulk of the money supply during this period, we compare bills (banknotes) in the hands of the public in Massachusetts with the same magnitude for Pennsylvania. We do this in Chart 7. The largest decline in bills in the hands of the public in Massachusetts is 15 percent (from approximately $\$ 7.3$ million in May of 1837 to approximately $\$ 6.2$ million in October of 1839 ). By May of 1841 , the bills in the hands of the public were virtually back to what they had been in May of 1837. In contrast, in Pennsylvania, between May and November of 1837, the bills in the hands of the public declined by 34 percent (from approximately $\$ 10.9$ million to approximately $\$ 7.2$ million.) And by May of 1841 , bills in the hands of the public were down by 64 percent to only $\$ 3.9$ million.

\section{Conclusion}

The role the Suffolk Bank played in the Panic of 1837 and its aftermath provides economists with a rare experiment in economic policy analysis. Economists generally do not have the luxury of carrying out real world experiments to determine the effects of alternative policies. The Suffolk Bank's experience, however, can be interpreted as such an experiment. Because the services provided by the Suffolk Bank to the banks of New England were unique to that part of the country, we can potentially identify the benefits of a bank providing a net-clearing system and acting as a lender-of-last-resort. The benefits appear to have been substantial, because New England's economy during and after the Panic of 1837 outperformed economies in the rest of the 
country-even economies that were not directly affected by the sharp decline in cotton prices that occurred over this period.

Having established at least a prima facie case that the Suffolk Bank made a difference, however, raises several questions. Why was the Suffolk Bank unique? That is, since it appears to have been so profitable (Smith, Rolnick, Weber 1998) and since it appears to have benefited the entire regional economy, why weren't such banks operating in other parts of the country? Our findings raise a related question: What motivated Suffolk to act in the public's interest? Did the public's interest and Suffolk's private interest happen to coincide, or was Suffolk more civic-minded than we give it credit for? Finally, future research needs to address a more fundamental question: Does the Suffolk experience support the view that unfettered market forces will find ways to discipline banks, or is Suffolk the exception to the rule that unfettered markets in banking are inherently unstable? 
References

Goldin, Claudia, and Robert A. Margo, 1989, "Wages, prices, and labor markets before the Civil War,” Working Paper 3198, National Bureau of Economic Research.

Gray, Lewis Cecil, 1933, History of Agriculture in the Southern United States to 1860. Vol. 2. Washington, D.C.: Carnegie Institution.

Hammond, Bray, 1957, Banks and Politics in America: From the Revolution to the Civil War. Princeton, N.J.: Princeton University Press.

Martin, Joseph G., 1886, Martin's Boston Stock Market: Eighty-Eight Years. Boston: Joseph G. Martin.

McGrane, Reginald Charles, 1924, The Panic of 1837: Some Financial Problems of the Jacksonian Era. Chicago: University of Chicago Press.

Mullineaux, Donald J., 1987, "Competitive monies and the Suffolk Bank System: A contractual perspective," Southern Economic Journal 53, 884-898.

Myers, Charles J., 1992, “A compilation of estimates of U.S. GNP, 1790-1840,” Manuscript, Golden Gate University, San Francisco.

National Bureau of Economic Research, 1966, Output, Employment, and Productivity in the United States After 1800: Studies in Income and Wealth. Vol. 30. New York: Columbia University Press.

Niles' National Register, 1837-1840, Vol. 52, various dates, pp. 114-292. Vol. 53, various dates, pp. 48, 280, 327. Vol. 54, various dates, pp. 48, 65, 81, 225. Vol. 55, January 12 , 1839, p. 307. Vol. 57, various dates, pp. 97-333. Baltimore, Md. (Vol. 52 published as Niles' Weekly Register.)

Redlich, Fritz, 1947, The Molding of American Banking: Men and Ideas. New York: Hafner. 
Rolnick, Arthur J., Bruce D. Smith, and Warren E. Weber, 1998, "Lessons from a laissez-faire payments system: The Suffolk Banking System (1825-58)," Federal Reserve Bank of St. Louis Review 80, 105-116.

Smith, Walter Buckingham, and Arthur Harrison Cole, 1935, Fluctuations in American Business, 1790-1860. Cambridge, Mass.: Harvard University Press.

Suffolk Bank, 1826, Directors' records, March 14, available at Baker Library, Harvard Business School.

Temin, Peter, 1969, The Jacksonian Economy. New York: W.W. Norton.

Timberlake, Richard H., Jr., 1960, “The specie circular and distribution of the surplus,” Journal of Political Economy 68, 109-117.

Trivoli, George, 1979, The Suffolk Bank: A Study of a Free-Enterprise Clearing System. London: Adam Smith Institute.

U.S. Bureau of the Census, 1975, Historical Statistics of the United States: Colonial Times to 1970. Two vols. Washington, D.C.: U.S. Government Printing Office.

Whitney, D. R., 1878, The Suffolk Bank. Cambridge, Mass.: Riverside Press. 


\section{Geographical Indices of Railroad-Stock Prices Quarterly, 1834-45}

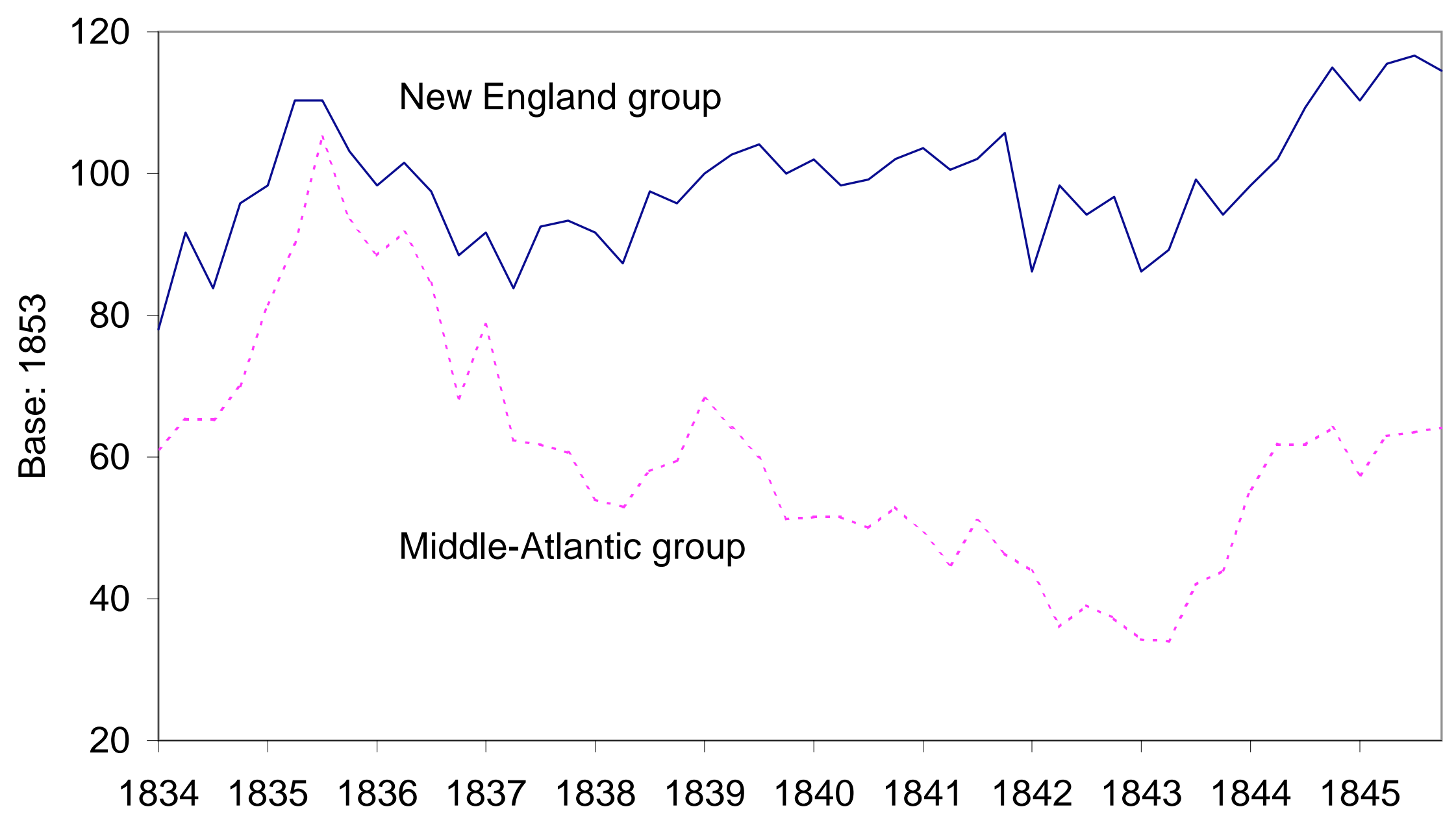




\section{Chart 2}

\section{Loans}

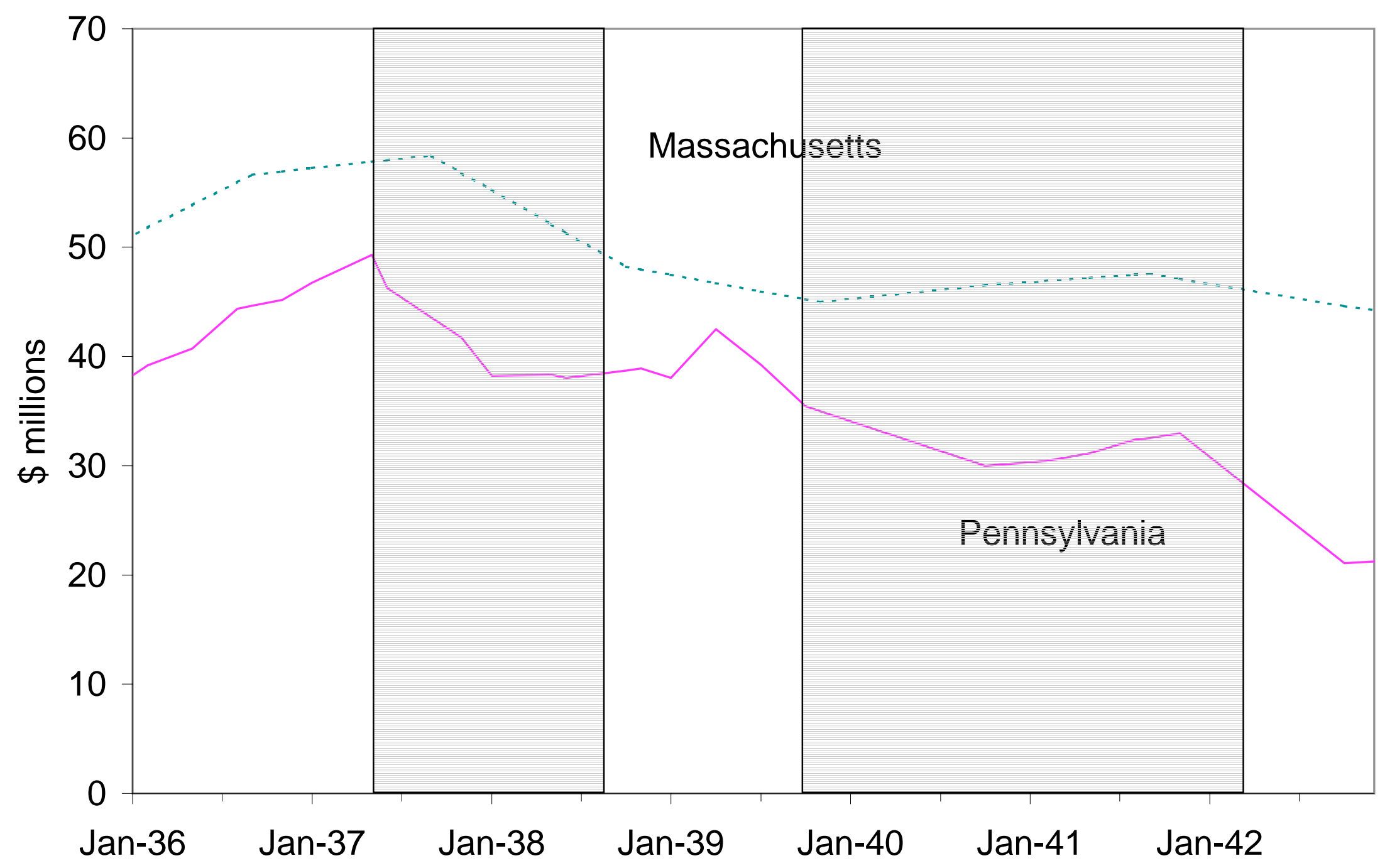


Chart 3

Bills of other banks

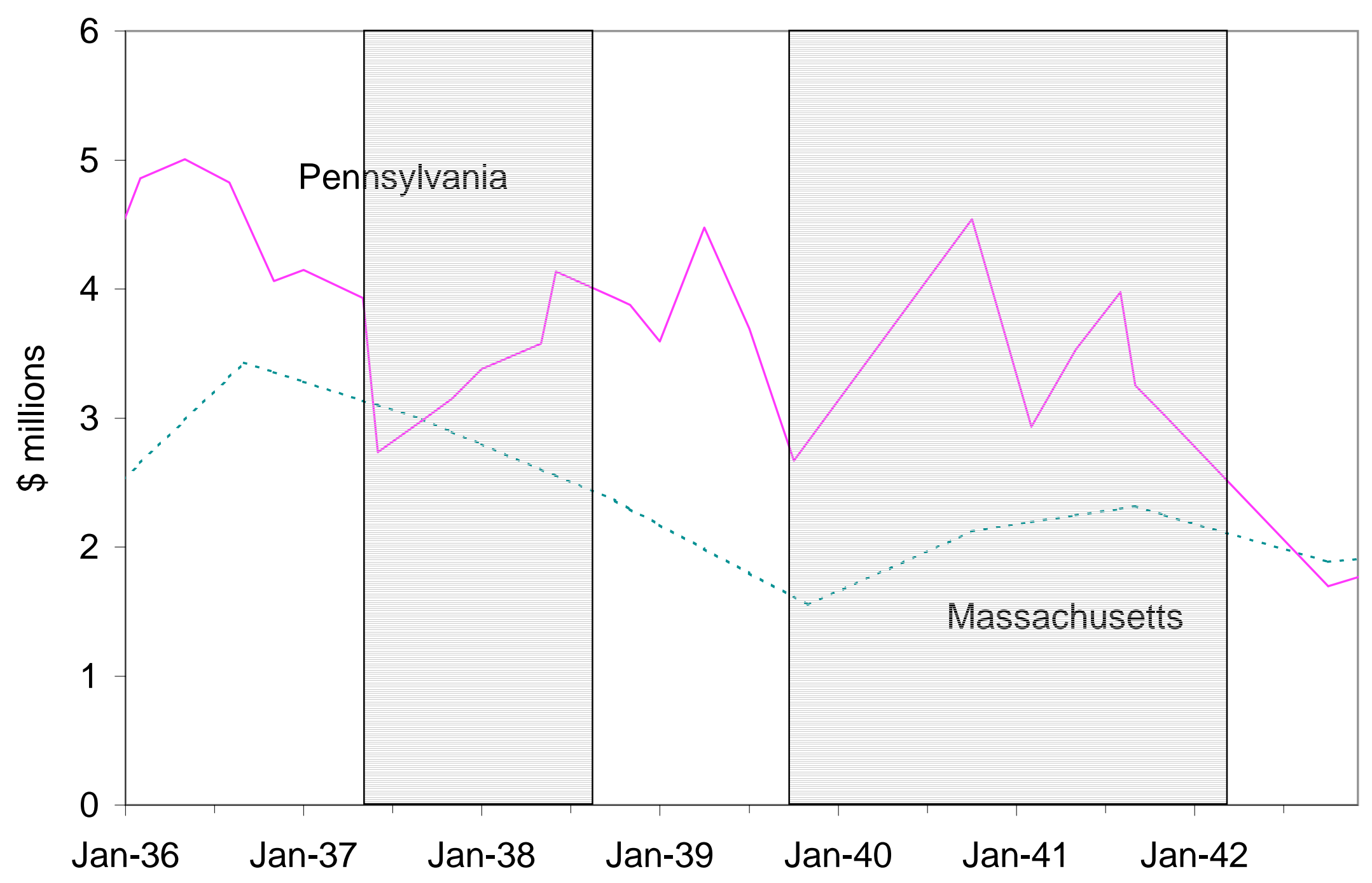


Chart 4

Suffolk Bank -- Due to and due from other banks

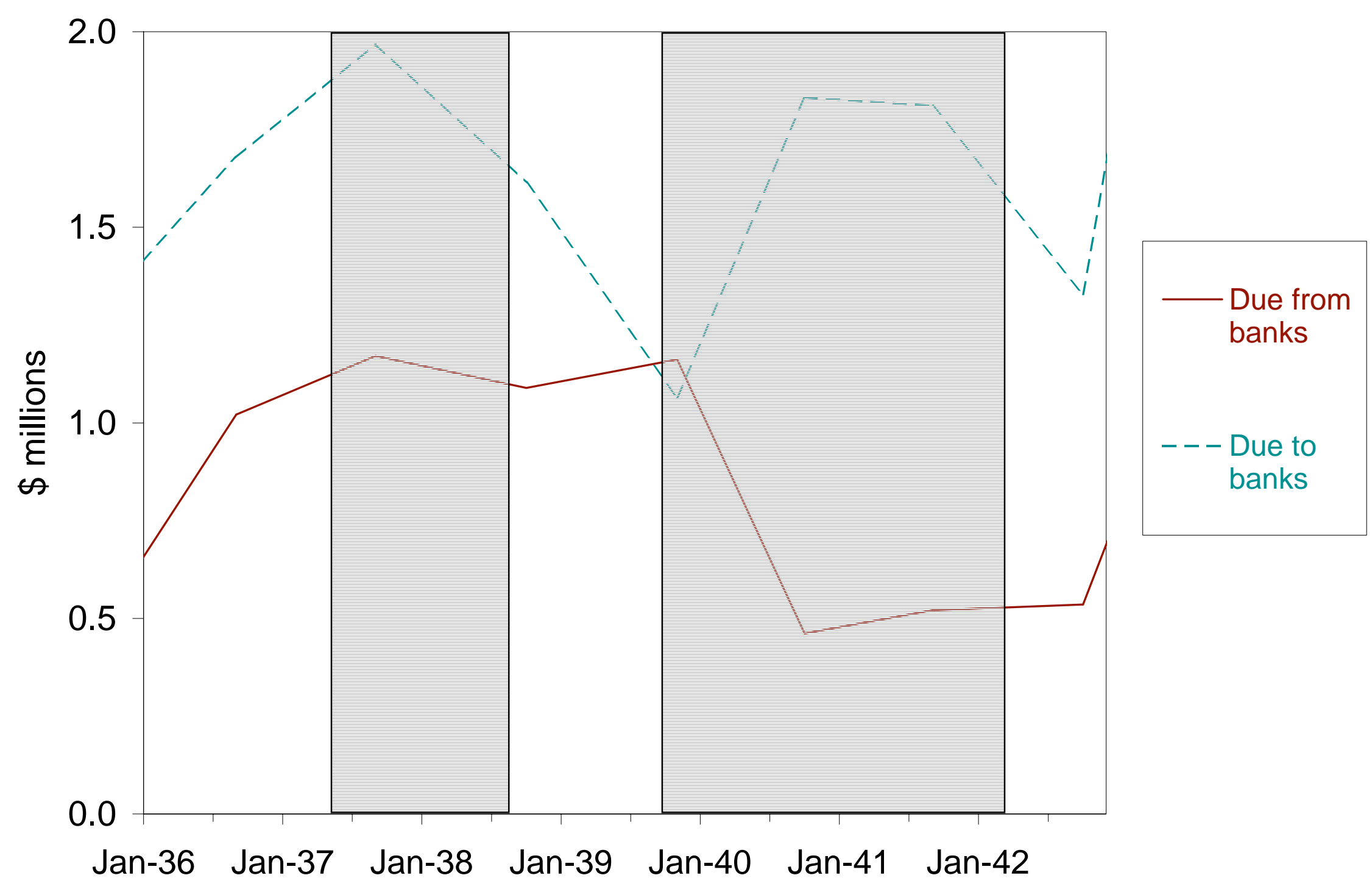




\section{Chart 5}

\section{Due from other banks}
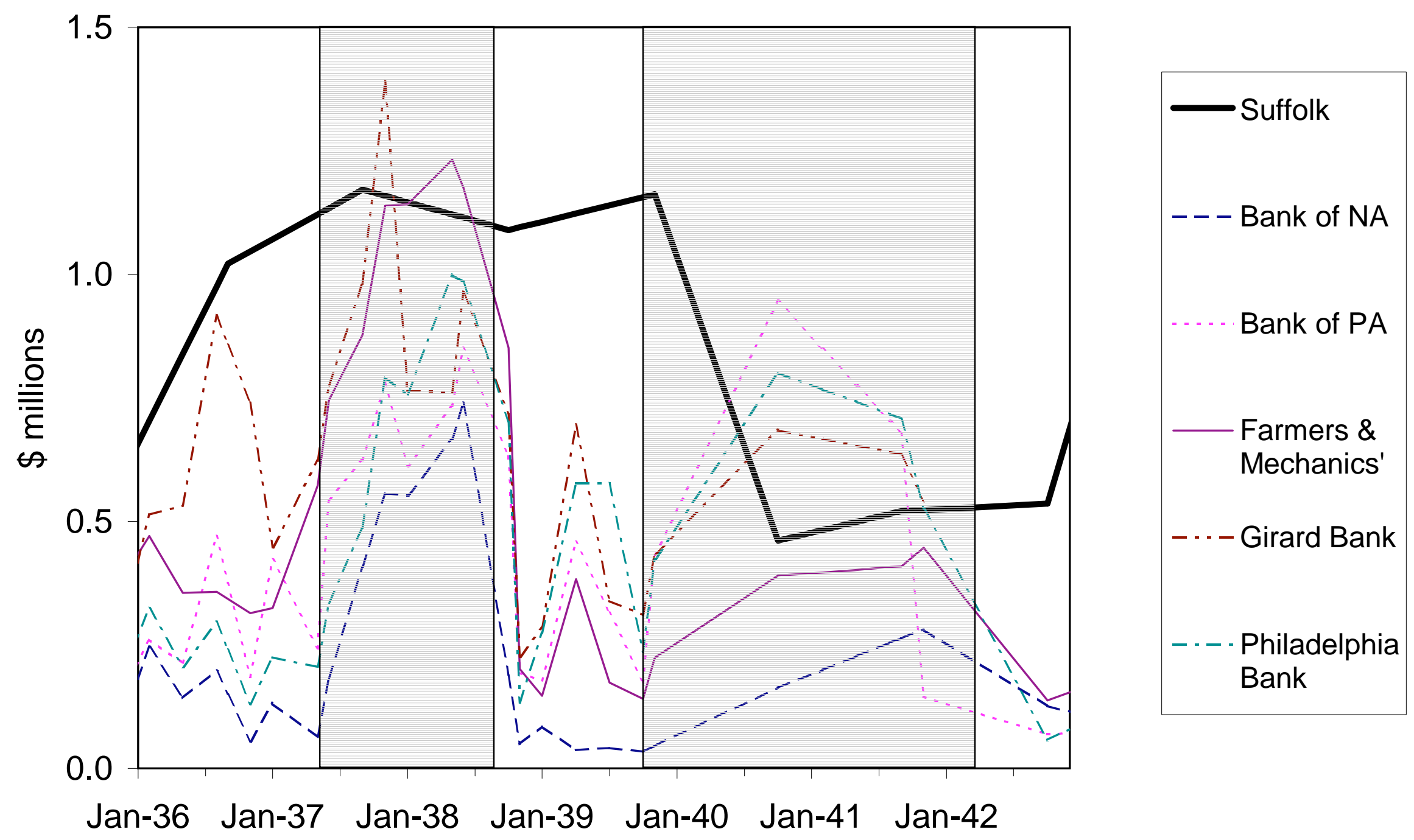
Chart 6

Ratios of Specie to Net Demand Liabilities, Massachusetts banks

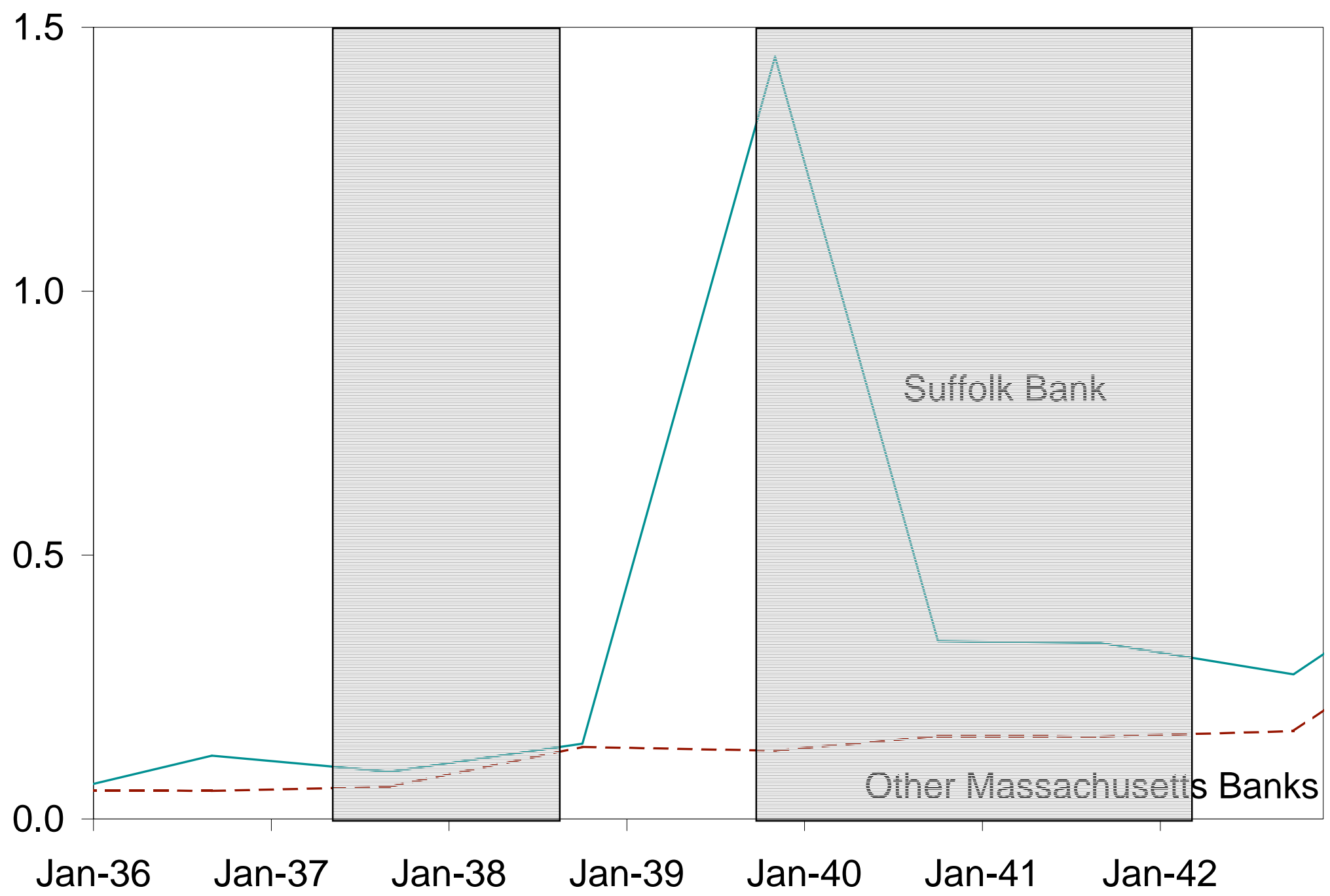




\section{Chart 7}

Bills in the hands of the public

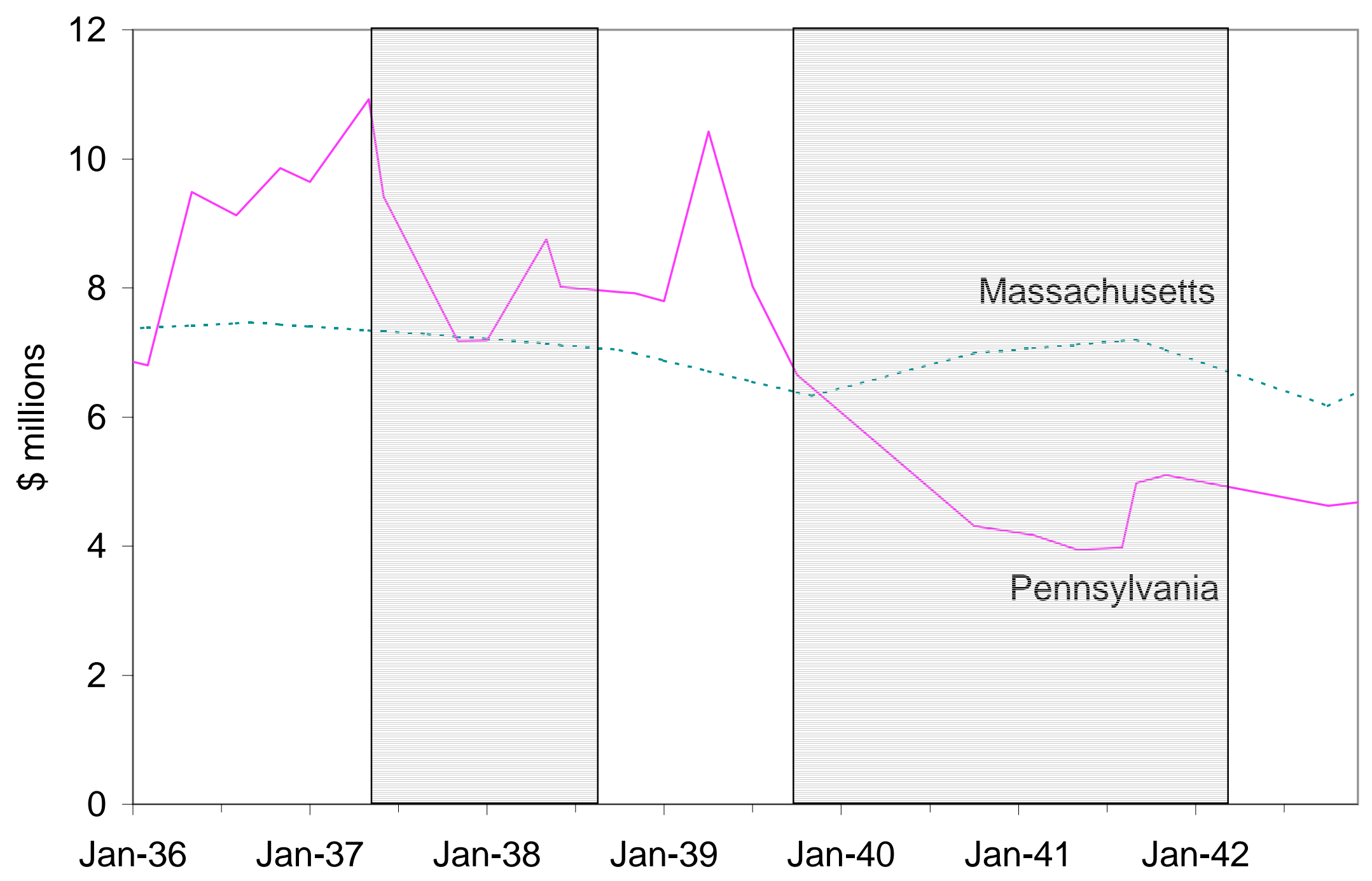

